\title{
Daily Life and Mathematic: Student and Content Constructions of the Concepts of Proposition, Theorem, and Proof
}

\author{
Ömer F. Çetin ${ }^{1, *}$ \\ ${ }^{1}$ Faculty Education, Erzincan University, Erzincan, Turkey \\ *Corresponding author: Faculty Education, Erzincan University, Yalnızbağ Yerleşkesi/24100, Erzincan, Turkey. \\ E-mail: fcetin80@hotmail.com
}

Received: March 2, $2015 \quad$ Accepted: March 22, $2015 \quad$ Online Published: April 9, 2015

doi:10.5430/wje.v5n2p63 URL: http://dx.doi.org/10.5430/wje.v5n2p63

\begin{abstract}
The aim of this study is to explore mathematics teaching department students' perceptions on the concepts of proposition, theorem, and proof which are very important for daily life, mathematical literacy and studying mathematics; the common mathematical content used in constructing these concepts; and whether these constructions and content construction match each other. A survey model was used for fulfilling the aim. The data was taken from 329 first-grade mathematics teaching department students' examination papers. The students were enrolled to an Education Faculty of a state university located in the Eastern Anatolia Region of Turkey and the data was collected in the first semesters of academic years 2009-2010, 2010-2011, 2011-2012, 2012-2013 and 2013-2014. The numerical distribution of the participants across years was, respectively, 82, 46, 52, 42 and 107. The data was descriptively analysed. It was found out that the students better structured the concept of proposition (when compared to the concepts of proof and theorem) in accordance with the content construction of concepts and the mathematical expressions used in construction of the concepts of theorem and proof by the students were far away from the mathematical expressions used in the content of these concepts.
\end{abstract}

Keywords: proposition; theorem; proof; mathematical literacy; mathematical thinking; daily life

\section{Introduction}

As in the example of definitions of the words "glass" and "stone" and then the formation of the propositions "Glass is a fragile material" and "I threw a stone", the logical inference from these propositions that "If I throw the stone, the glass is broken" and the affirmation of the logical inference for "breaking the glass by throwing a stone at it", people live a life based on definitions, propositions, theorems, and proofs. Namely, first, the definitions, then propositions, and from these propositions, theorems are produced and proofs are provided. Similarly, all the things which are wanted to be analysed in Mathematics are first defined, and then turned into propositions, and finally, with the help of these propositions, theorems are obtained (Heinze and Reiss, 2003; Nasibov and Kaçar, 2005; Nasibov and Yetim, 2008). As definition is not more than explaining the other people which idea the term defined refers to with words, the best definition is made by listing the pure ideas collected in the referent of the term defined (Bravo, 2010). In brief, identifying the meaning of a term is defining that term (Milli Ĕgitim Bakanlığ $[\mathrm{MEB}], 2011$ ). Terms are divided into subcategories as "well-defined terms" and "intuitively-defined (or undefined) terms". If every word of a definition cannot be explained with simpler words, it is intuitively-defined, if it is, it well-defined. For example, the terms "point", "line", and "plane" used in geometry are intuitively-defined terms. Terms can be put in order with axioms (postulates in geometry) or propositions (Bravo, 2010), which allows us to form theorems and mathematical structures.

\subsection{Some Resources Used in Teaching These Subjects and Contents Used in These Resources}

Students gain the first detailed information about propositions, axioms, theorems, and proofs in the High-school $1^{\text {st }}$ grade Mathematics course-book prepared by the Ministry of National Education (MEB) in Turkey as in follows:

In mathematics, stating an exact inference is defined as judgement. The statements about which we can reach an ultimate judgement in mathematics are called propositions. The propositions regarded to be true are called axioms, and the propositions we need to prove are called theorems. A theorem consists of one hypothesis and one judgement. In the theorem $p \Rightarrow q$, $p$ is called hypothesis and $q$ is called judgement. In a theorem, both $p$ (hypothesis) and $q$ (judgement) 
should be true. While showing that the judgement of a theorem is true is called proof, reaching the judgement of a theorem from its hypothesis is called proving the theorem. While proving a theorem, previous definitions, axioms, and theorems are used. The greatest difference of theorem from axiom is the requirement for proof (MEB, 2011).

On the other hand, at the tertiary level, the terms proposition, theorem, and proof are explained as follows:

Proposition is defined as the statement which can be matched with one, only one of "true" and "false". The propositions which have been proven in advance are called theorems (Akkaş, Hacısalihoğlu, Özel and Sabuncuoğlu, 1998, pp. 1, 5).

The statements which contain a true or false judgement are called propositions. Say $p$ is a true proposition: If the prerequisiteof $\mathrm{p} \Rightarrow \mathrm{q}$ is true, the proposition of $\mathrm{p} \Rightarrow \mathrm{q}$ is called theorem (Dönmez, 1987, pp. 1, 5).

If a sentence is definitely true or definitely false, this sentence is called proposition. When a proposition as $p \Rightarrow q$ is given, if this proposition is "true", it is called theorem.In the theorem of $\mathrm{p} \Rightarrow \mathrm{q}, \mathrm{p}$ is called hypothesis and q is called judgment. The process of showing that a proposition like $\mathrm{p} \Rightarrow \mathrm{q}$ is "true" is called proving the theorem (Irmak, 2008, pp. $3,40)$.

The statement which is not both true and false though it is either true or false is called a proposition. Indicating that some propositions which are supposed or given to be true altogether require a proposition to be true is called theorem. The proposition which is the concurrent affirmation of the propositions whose truth is supposed or given is named the hypothesis of the theorem and the theorem whose truth is put forward is named the consequent of the theorem. Showing that hypothesis requires a consequent is called mathematical proof. If the hypothesis in a theorem is shown as $\mathrm{H}$ and the consequent as $\mathrm{R}$, proving the theorem mathematically means showing that $\mathrm{H} \Rightarrow \mathrm{S}$ is true as long as $\mathrm{H}$ is true (Özer, Çoker and Taş, 1999, pp. 1, 18).

Proposition is a case just like that in an English sentence which has a subject and a predicate. Propositions can be either true or false. A mathematical proof is a system which involves a series of valid formulae each line of which is an axiom or a consequent of an applied Modus Ponen (the compound proposition of $[p \Lambda(p \Rightarrow q)] \Rightarrow q$, or a hypothesis or a lemma. The last formula of this system is called theorem (Hirst and Hirst, 2004, pp.1, 15).

The statements which convey a judgement and about which it is meaningful to say true or false are called propositions. The inferences drawn from axioms according to the principles of logic are called theorems. A reason should be given for each step of proving theorems. This reason can be only either an axiom or a theorem proven in advance. It is very important to take many details into account in a preliminary work on any phenomenon. However, as the course progresses, we can complete the proof by involving fewer details as a result of using some techniques repeatedly. Say we are given an axiomatic system the axioms of which are $a_{1}, a_{2} \ldots, a_{n}$; and $s$ is a meaningful proposition identified according to the conventional terms of the system or its defined terms: If $s$ is the logical outcome of the system, it is a theorem. In other words, if the truth of axioms requires the truth of s, s is an axiom. This can be symbolically given as;

Given $\mathrm{a}=\mathrm{a}_{1} \Lambda \mathrm{a}_{2} \Lambda \ldots \Lambda \mathrm{a}_{\mathrm{n}}$, the consequent is $\mathrm{a} \Rightarrow \mathrm{s}$. The proof of $\mathrm{s}$ is a finite series of propositions each of which is an axiom or a non-contradictory consequent of the previous propositions in a way as the last proposition is $\mathrm{s}$.

Most theorems are expressed as requirements.

Say $\mathrm{s}=(\mathrm{p} \Rightarrow \mathrm{q})$, then, the assumption thats is a theorem is equal to $\mathrm{s} \Rightarrow(\mathrm{p} \Rightarrow \mathrm{q}$. At the same time, it can be seen that $[a \Rightarrow(p \Rightarrow q)] \Leftrightarrow[(a \Lambda p) \Rightarrow q]$. The case where a is always true shows that the value of truth of the compound proposition $[a \Rightarrow(p \Rightarrow q)]$ is the same as the truth value of $(p \Rightarrow q)$. The direct proof of $(p \Rightarrow q)$ is finding the truth of $\mathrm{q}$ by assuming that $\mathrm{p}$ and axioms are true (Çelebi and Çakar, 1993, pp.1, 9, 16, 28, 29).

While there are no differences between the definitions of proposition, some of the definitions of theorem and proof reciprocally refer to each other and they do not include explanatory information about how a theorem can be formed and how a proof can be produced. This case affects students' constructions of these concepts and consequents in dealing with and conveying theorems together with their proofs (usually as memorization). Furthermore, these definitions of theorem and proof cause the formation of questions such as "Are there propositions whose rightness cannot be proven?", "Which propositions can be proven in terms of their truth?", "What kinds of differences are there between true propositions and those whose truth has been proven?", "How can the truth or falsity of a proposition be known if every proposition cannot be proven?", "Why do we not name some theorems at the end of proving process theorem even though we name them proof and prove them?".

Existence of numerous national and international studies on individuals' weaknesses or misconceptions about theorem and proof (Almeida, 2000; Arslan and Yıldız, 2010; Arslan,2007; Aydoğdu, Olkun and Toluk, 2003; Bahtiyari, 2010; Coşkun, 2009; Dane, 2008; Dreyfus, 1999; Güven, Çelik and Karataş, 2005; Harel and Sowder, 1998; İmamoğlu, 2010; 
Jones, 2000; Moore, 1990, 1994; Moral, Uğurel, Türnüklü, and Yeşildere, 2006; Özer and Arıkan, 2002; Raman, 2002, 2003; Recio and Godino, 2001; Sarı, Altun, and Aşkar, 2007; Selden and Selden, 2003; Shipley, 1999; Stylianides, Stylianides and Philippou, 2007; VanSpronsen, 2008; Weber, 2001, 2005) shows that the gaps or misconceptions related to theorem and proof are not peculiar only to Turkish context. Studies, among these subjects, have focused on proof which is regarded very important for developing mathematical thinking (Hanna, 2000; Moralı, Köroğlu and Çelik, 2004; Moralı et al., 2006) and can be used as a means of persuading people (Harel, 2008; Harel and Sowder, 1998, 2007) (persuading people would decrease the undesirable social events). Proof shows thereasons beyond explaining the truth or falsity of each case (Tall and Mejia-Ramos, 2006). Proof is important for also doing mathematics, establishing a mathematical communication, and recording mathematics (Schoenfeld, 1994). With this nature, proof is productive (Coe and Ruthven, 1994; Martin and Harel, 1989) and differs from affirmation. Beside these, in NCTM in 2000, it is reported that proof is an effective way which can be used in developing and explaining instincts. Studies with the purpose to find out the reasons underlying the difficulties with proof which is an important phenomenon show that students cannot remember what proof is (Moore, 1994; Raman, 2003), do not have right ideas about what a mathematical proof consists of (Weber, 2001), and cannot understand the concept of proof (Dane, 2008; Güler and Dikici, 2012; Moore, 1994). Defining a subject matter difficult or easy vary according to various criteria. Generally, as the mathematical subjects cover abstract and complex information, they are considered to be difficult. Nevertheless, the subjects of mathematics can be taught and learned. Sometimes, what is learned may not be enough for doing mathematics because learning mathematics and doing mathematics hold different meanings. Doing mathematics involves, in addition to learning mathematics, building relations among what is learned in consistence with the nature of mathematics, making logical inferences, and proving these inferences, again, in consistence with the nature of mathematics. The constructions of these concepts will occur in the learning process. The people who have a crucial role in this process are teachers. The field knowledge needed to be effective in mathematics teaching (Bayazit and Aksoy, 2010; Escudero and Sanchez, 2002; Özmantar and Bingölbali, 2010; Tirosh, Even and Robinson 1998; Yeşildere and Akkoç, 2010) covers all of the views and perceptions of mathematics teachers about the definitions, axioms, undefined concepts, methods of proving, correlation, rules, and formulae used in the teaching of mathematical subjects (Ball, 1991; Shulman, 1986).

Therefore, studies aiming at exploring pre-service teachers and teachers" opinions about and their views of proof and their processes of proving (Almeida, 2000, 2003; Dane, 2008; Dickersen, 2006; Harel and Sowder, 1998; İskenderoğlu, Baki and Palanc1, 2011; Jones, 1997, 2000; Knuth, 2002; Moralı et al., 2006; Raman, 2002, 2003; Recio and Godino, 2001; Solomon, 2006; Stylianides, et al., 2007; Weber, 2001) have also been conducted. In addition, it is suggested that teaching programs should cover some activities for developing and evaluating mathematical discussions and proofs (NCTM, 2000). In this sense, the subjects proposition, theorem, and proof which are necessary especially for doing mathematics are the subjects which are always worth studying on.

\subsection{The Purpose of the Study}

This study aims to identify the common mathematical contents the students have used in constructing the concepts of proposition, theorem, and proof, which are very important for their daily life, mathematical literacy, and doing mathematics, between the years 2009 and 2014 and, in this way, to explore whether students' constructions and the content constructions of these concepts match each other. For this purpose, answers were sought for the following sub-problems for five years;

1. What are the common mathematical contents the students have used in constructing the concepts of proposition, theorem, and proof?

2. Do the students' constructions of the concepts of proposition, theorem, and proof and the content constructions of these concepts match each other?

\section{Methodology}

As it was aimed to explore the common mathematical contents used in constructing the concepts of proposition, theorem, and proof for a period of five years, therefore a general survey model which aims to gather many individuals' general ideas on a specific topic and reach a general conclusion (see Karasar, 2008) was used. The data collected through a document analysis of the written materials involving information on the phenomena to be studied was described by using a content analysis (Yıldırım and Şimşek, 2005).

\subsection{Participants}

The participants of the study consisted of 329 first-grade students who were given the Abstract Mathematics course at 
the Department of Mathematics Teaching of an Education Faculty of a state university located in the Eastern Anatolia Region of Turkey between the years 2009 and 2014. The distribution of the participants across the academic years was respectively 82 (2009-2010), 42 (2010-2011), 52 (2011-2012), 46 (2012-2013), and 107 (2013-2014). Some of these students had to take the Abstract Mathematics course twice or more since they failed in the examinations before. The students at the department are taught the concepts of "proposition", "theorem", and "proof" in the Mathematics course at the first grade of high school and at the 3-hour Abstract Mathematics course in the second semester of the first year.In addition, these students are given a 5-hour General Mathematics in the first semester of the first year and a 3 -hour Geometry course in the second semester of the same year.

\subsection{Data Collection Instrument}

In this study, the data was collected through final examination papers. In the final examination, one of the open-ended questions was asked for the purpose of collecting the data of this study. Not the same question was asked for four years. Each year, the content of the question was changed. For example, while the question was asked as "What are set, theorem, correlation, proposition, and proof? Explain" in the first year, in the second year, it was changed into "What are theorem, function, proposition, family of sets, and proof? Explain". During the examinations, the general examination rules of examination of the faculty were followed. Since the examination results would directly affect their academic achievement, it is naturally supposed that they answered the questions using their all knowledge on the subject matter and their full attention with the desire to give the right answer. After the examination, no negative feedback was shared by either the examination invigilators or the students.

\subsection{Data Collection and Analysis}

During a two-lesson-hour time (100 min.) which is the formal duration allotted for final examinations, students were asked to give written answers to the questions. As all the examination rules should be followed during the entire time of examination, any interaction among students was out of question. The data was first subjected to a content analysis and then it was descriptively (Yıldırım and Şimşek, 2005) analysed. Using a key, examination papers were evaluated one by one (after the evaluation of each question, the papers were reordered. The examination papers were numbered from one to the number of the students attended the examination each year according to the year of enrolment (as 2009-09/1 and 2013-13/1) and computerized. For the answers given, the themes, "proposition", "theorem", and "proof" were set. Later, these themes, as given in the tables (Not given here for avoiding repetition) in the section of "Findings", were analysed under the categories and sub-categories formed according to the common emphasis points of student answers and interpreted with direct quotations. As a common definition was given for only proposition in the references in "Introduction" and supposing that students may have benefited from different sources, under the theme "proposition", the categories "right", "false", and "no answer" were used.

\section{Findings}

In this part, findings related to sub-problem of the research were given in separate headings.

\subsection{The Common Mathematical Contents Used in Constructing Proposition, Theorem, and Proof}

\subsubsection{Proposition}

The distribution of students' responses to the question "Define proposition" by years and categories is given in Table 1.

Table 1. The Distribution of Students' Responses on Proposition by Years and Categories

\begin{tabular}{lcccccccccccc}
\hline & \multicolumn{2}{c}{$2009-2010$} & \multicolumn{2}{c}{$2010-2011$} & \multicolumn{2}{c}{$2011-2012$} & $2012-2013$ & \multicolumn{2}{c}{$2013-2014$} & \multicolumn{2}{c}{5 years } \\
\cline { 2 - 13 } Category & $\mathrm{N}$ & $\%$ & $\mathrm{n}$ & $\%$ & $\mathrm{n}$ & $\%$ & $\mathrm{n}$ & $\%$ & $\mathrm{n}$ & $\%$ & $\mathrm{n}$ & $\%$ \\
\hline Right & 39 & 47.56 & 24 & 57.14 & 36 & 69.23 & 30 & 65.22 & 47 & 43.93 & 176 & 53.50 \\
False & 31 & 37.81 & 17 & 40.48 & 16 & 30.77 & 13 & 28.26 & 40 & 37.38 & 117 & 35.56 \\
No answer & 12 & 14.63 & 1 & 2.38 & - & - & 3 & 6.52 & 20 & 18.69 & 36 & 10.94 \\
Total & 82 & 100 & 42 & 100 & 52 & 100 & 46 & 100 & 107 & 100 & 329 & 100 \\
\hline
\end{tabular}

As shown in Table 1, in the mean of five years, whereas the constructions of the concept of proposition of more than half of $(53.50 \%)$ the students were in consistency with the content structure of the concept, the constructions of slightly more than of one out of three $(35.56 \%)$ of them were not. Nearly one out of ten $(10.94 \%)$ of the students 
could not construct the proposition. The construction of the concept of proposition in consistency with the content structure of the concept was highest (69.23\%) in the academic year 2011-2012 while it was lowest (43.93\%) in 2013-2014. The construction of the concept not consistent with the content structure of the concept was highest (40.48\%) in the 2010-2011 and lowest (28.26\%) in 2012-2013. Whereas all the students made a construction for the concept in the 2011-2012, the number of the students who did not make any construction was highest (18.69\%) in the 2013-2014. Although the rate of the constructions consistent with the content structure of the concept increased from the first year to the second and from the second year to the third regularly and at a rate which can be regarded high, the rate decreased slightly from the third year to the fourth and from the fourth year to the fifth at a rate which can be regarded high and it was even below the rate of the first year.

\subsubsection{Theorem}

The distribution of students' responses to the question "Define theorem" by years and categories is given in Table 2 .

Table 2. The Distribution of Students' Responses on Theorem by Years and Categories

\begin{tabular}{|c|c|c|c|c|c|c|c|c|c|c|c|c|}
\hline \multirow[b]{2}{*}{ Categories } & \multicolumn{2}{|c|}{$2009-2010$} & \multicolumn{2}{|c|}{$2010-2011$} & \multicolumn{2}{|c|}{ 2011-2012 } & \multicolumn{2}{|c|}{$2012-2013$} & \multicolumn{2}{|c|}{ 2013-2014 } & \multicolumn{2}{|c|}{5 years } \\
\hline & $\mathrm{n}$ & $\%$ & $\mathrm{n}$ & $\%$ & $\mathrm{n}$ & $\%$ & $\mathrm{n}$ & $\%$ & $\mathrm{n}$ & $\%$ & $\mathrm{n}$ & $\%$ \\
\hline $\begin{array}{l}\text { Associating with only } \\
\text { "proof" }\end{array}$ & 18 & 21.95 & 2 & 4.76 & 2 & 3.85 & 7 & 15.22 & 34 & 31.78 & 63 & 19.15 \\
\hline $\begin{array}{l}\text { Associating "Truth with } \\
\text { proving-accepting" }\end{array}$ & 41 & 50 & 31 & 73.81 & 34 & 65.38 & 30 & 65.22 & 25 & 23.37 & 161 & 48.94 \\
\hline $\begin{array}{l}\text { Associating "Truth or } \\
\text { falsity with } \\
\text { proving-accepting" }\end{array}$ & 6 & 7.32 & 3 & 7.14 & 4 & 7.69 & 4 & 8.70 & 14 & 13.08 & 31 & 9.42 \\
\hline $\begin{array}{l}\text { Associating with } \\
\text { "Hypothesis } \\
\text { (assumption) and } \\
\text { judgement } \\
\text { (Consequent) concepts" }\end{array}$ & 2 & 2.43 & 4 & 9.53 & 10 & 19.23 & 1 & 2.17 & 3 & 2.80 & 20 & 6.08 \\
\hline Other & 8 & 9.76 & 1 & 2.38 & 2 & 3.85 & 3 & 6.52 & 11 & 10.28 & 25 & 7.60 \\
\hline No answer & 7 & 8.54 & 1 & 2.38 & - & - & 1 & 2.17 & 20 & 18.69 & 29 & 8.81 \\
\hline Total & 82 & 100 & 42 & 100 & 52 & 100 & 46 & 100 & 107 & 100 & 329 & 100 \\
\hline
\end{tabular}

In their responses to the question "Define theorem", in constructing the concept of theorem, students used the mathematical contents "proving-accepting the truth" most (48.94\%) and "Hypothesis (assumption) and judgement (Consequent)" least (6.08\%). Whereas use of the mathematical content "proving accepting the truth" was $50 \%$ in the first year, it decreased to $23.37 \%$ in the fifth year. On the other hand, whereas use of the mathematical content "Proving-accepting truth or falsity" was $7.32 \%$ in the first year, it increased to $13.08 \%$ in the fifth year. Use of the mathematical content of theorem "hypothesis and consequent" is the mathematical content which was highest $(19.23 \%)$ in the third year and has the lowest overall mean (6.08\%) for five years. In addition, the rate of the students who could not construct theorem was much higher (18.69\%) in the last year than the other years.

\subsubsection{Proof}

The distribution of students' responses to the question "Define proof" by years and categories is given in Table 3 .

Students, in their constructions in their answers to the question "Define proof", used the mathematical content "theorem" most (44.38\%) and "axiom" least (1.52\%). Whereas use of the mathematical content theorem was $50 \%$ in the first year, it decreased to $39.25 \%$ in the last year. Students' percentages of using the mathematical contents "proposition" and "formula-expression-operation-problem-question-judgement and equality" were nearly equal to each other over the five-year term. Percentage of the use of the mathematical content "proposition" increased in the first three years, and then decreased; and, in the last year, it reached its lowest percentage. While the use of the mathematical content "formula-expression-operation-problem-question-judgement and equality" has the highest percentage in the fourth year, the means of other years were very close to the rate in that year. An interesting finding is that the use of the mathematical contents "hypothesis and consequent", which is already low has its lowest percentage in the fifth year. There were great increases in the percentages of the students who could not construct the 
concept of proof in the last two years. Nearly one out of five (18.54\%) of them could not construct the concept of proof.

Table 3. The Distribution of Students' Responses to the Question on Proof by Years and Categories

\begin{tabular}{|c|c|c|c|c|c|c|c|c|c|c|c|c|}
\hline \multirow[b]{2}{*}{ Categories } & \multicolumn{2}{|c|}{ 2009-2010 } & \multicolumn{2}{|c|}{$2010-2011$} & \multicolumn{2}{|c|}{ 2011-2012 } & \multicolumn{2}{|c|}{$2012-2013$} & \multicolumn{2}{|c|}{ 2013-2014 } & \multicolumn{2}{|c|}{5 Years } \\
\hline & $\mathrm{n}$ & $\%$ & $\mathrm{n}$ & $\%$ & $\mathrm{n}$ & $\%$ & $\mathrm{n}$ & $\%$ & $\mathrm{n}$ & $\%$ & $\mathrm{n}$ & $\%$ \\
\hline Associating with theorem & 41 & 50 & 24 & 57.14 & 20 & 38.46 & 19 & 41.30 & 42 & 39.25 & 146 & 44.38 \\
\hline Associating with Proposition & 11 & 13.41 & 6 & 14.29 & 11 & 21.15 & 4 & 8.70 & 7 & 6.54 & 39 & 11.85 \\
\hline $\begin{array}{l}\text { Associating with Hypothesis and } \\
\text { Consequent }\end{array}$ & 6 & 7.32 & 3 & 7.14 & 8 & 15.38 & 4 & 8.70 & 1 & 0.94 & 22 & 6.69 \\
\hline Associating with Axiom & 1 & 1.22 & - & - & 1 & 1.92 & 2 & 4.35 & 1 & 0.94 & 5 & 1.52 \\
\hline Associating with Hypothesis & 1 & 1.22 & 2 & 4.76 & 4 & 7.70 & - & - & 3 & 2.80 & 10 & 3.04 \\
\hline $\begin{array}{l}\text { Associating with Formula, } \\
\text { Expression, Operation, Problem, } \\
\text { Question, Equation, Judgement } \\
\text { etc. }\end{array}$ & 10 & 12.20 & 6 & 14.29 & 6 & 11.54 & 9 & 19.56 & 15 & 14.02 & 46 & 13,98 \\
\hline No answer & $\begin{array}{l}12 \\
82\end{array}$ & $\begin{array}{c}14,63 \\
100\end{array}$ & $\begin{array}{c}1 \\
42\end{array}$ & $\begin{array}{c}2,38 \\
100\end{array}$ & $\begin{array}{c}2 \\
52\end{array}$ & $\begin{array}{c}3,85 \\
100\end{array}$ & $\begin{array}{c}8 \\
46\end{array}$ & $\begin{array}{c}17,39 \\
100\end{array}$ & $\begin{array}{c}38 \\
107\end{array}$ & $\begin{array}{c}35.51 \\
100\end{array}$ & $\begin{array}{c}61 \\
329\end{array}$ & $\begin{array}{c}18,54 \\
100\end{array}$ \\
\hline
\end{tabular}

\subsection{Match between the Concept Construction and the Content Constructions of the Concepts}

\subsubsection{Proposition}

Sub-categories of the category of "false" student answers to the question "Define proposition" and their distribution by years are shown in Table 4 .

Table 4. Sub-categories of the Category of "False" Student Answers to the Question on Proposition and Their Distribution by Years

\begin{tabular}{|c|c|c|c|c|c|c|c|c|c|c|c|c|}
\hline \multirow[b]{2}{*}{ Sub-categories } & \multicolumn{2}{|c|}{$2009-2010$} & \multicolumn{2}{|c|}{ 2010-2011 } & \multicolumn{2}{|c|}{ 2011-2012 } & \multicolumn{2}{|c|}{ 2012-2013 } & \multicolumn{2}{|c|}{ 2013-2014 } & \multicolumn{2}{|c|}{5 Years } \\
\hline & $\mathrm{N}$ & $\%$ & $\mathrm{~N}$ & $\%$ & $\mathrm{n}$ & $\%$ & $\mathrm{~N}$ & $\%$ & $\mathrm{n}$ & $\%$ & $\mathrm{~N}$ & $\%$ \\
\hline $\begin{array}{l}\text { The judgements, } \\
\text {-statements- sentences } \\
\text { whose truth or falsity is } \\
\text { not completely known or } \\
\text { exact or still being } \\
\text { pursued or debated }\end{array}$ & 16 & 51.61 & 8 & 47.06 & 8 & 50 & 8 & 61.54 & 17 & 42.5 & 57 & 48.72 \\
\hline $\begin{array}{l}\text { The } \\
\text { judgements-statements-sen }\end{array}$ & & & & & & & & & & & & \\
\hline $\begin{array}{l}\text { tences-hypotheses whose } \\
\text { truth orfalsity cannot/can } \\
\text { be proven }\end{array}$ & 8 & 25.81 & 7 & 41.18 & 4 & 25 & 4 & 30.77 & 13 & 32.5 & 36 & 30.77 \\
\hline Others & 7 & 22.58 & 2 & 11.76 & 4 & 25 & 1 & 7.69 & 10 & 25 & 24 & 20.51 \\
\hline Total & 31 & 100 & 17 & 100 & 16 & 100 & 13 & 100 & 40 & 100 & 117 & 100 \\
\hline
\end{tabular}

As given in Table 4, nearly half of the students (48.72\%) who constructed the concept of "proposition" not consistent with its content construction defined proposition as "The judgements,-statements- sentences whose truth or falsity is not completely known or exact or still being pursued or debated" and nearly one out of three of them (30.77\%) defined it as "The judgements-statements-sentences-hypotheses whose truth or falsity cannot/can be proven". In addition, in the answers in nearly one out of five of the students $(20.51 \%)$ whose constructions were not consistent with the content construction of the concept of proposition, no common mathematical content was found. The students in the first group wrote some of the conditions that prevent a sentence from being a proposition. The expressions of the students coded 09/17, 10/16, 11/9, 12/22, in this group, are given below.

$09 / 17$. They are the statements whose truth or falsity is not precise.

$10 / 16$. The statements whose truth or falsity is not precise are called propositions. 
11/9. The statements whose truth or falsity is not precise and not either true or false are called propositions.

$12 / 22$. They are the statements whose truth or falsity is not known.

13/88. The statements whose truth or falsity is not precise are called propositions.

The students in the second group defined proposition as "The judgements-statements-sentences-hypotheses whose truth or falsity cannot/can be proven". These students perceived proposition as an argument that should necessarily be proven. Of the students in this group, the expressions of those coded 09/46, 10/22, 11/49, 12/35 and 13/55 are given below.

09/46. They are the statements whose truth cannot be proven.

10/22. They are the sentences which can be either true or false but not proven.

$11 / 49$. They are the judgements accepted to be true but not proven yet.

$12 / 35$. It has not been proven to be true or false yet. It is a hypothesis.

$13 / 55$. They are the statements whose truth or falsity has not been proven.

\subsubsection{Theorem}

Sub-categories of each of the categories of the answers given by students to the question "Define theorem" and their distribution by years are shown in Table 5 .

As shown in Table 5, the students who constructed the concept of theorem with "proof" did this most (38.71\%) by associating it with proposition. This result was evidenced most (50\%) in 2010-2011 and 2011-2012 academic years and least (28.57\%) in the 2012-2013 academic year. Of the students who constructed the concept of theorem with the concept of "proof", more than one out of three $(33.87 \%)$ did this by associating it with "statements/knowledge/problems/things". Whereas this case occurred most (71.43\%) in the 2011-2012 year, no student made such an association in the 2010-2011 year. Nearly one out of four of the students who constructed the concept of theorem with the concept of "proof" $(25.81 \%)$ did this by associating it with "axiom/hypothesis". While this association was not made in 2010-2011 and 2011-2012 years, it was highest (36.36\%) in the 2013-2014. The expressions of the students coded $09 / 20,11 / 44$ and 13/21 in this group are given below.

09/20. They are the propositions which are accepted after being proven.

11/44. The statements which can be proven are called theorems.

13/21. They are the axioms which are accepted without proof.

The students who constructed the concept of theorem with "proving-accepting truth" did this by associating it most $(61.71 \%)$ with "proposition" and least $(8.70 \%)$ with "axiom/hypothesis". Also, nearly one out of three of these students $(29.81 \%)$ constructed theorem with "statements/knowledge/problems/things/judgements". Whereas the percentage of the students who constructed theorem with "proposition" and "statements/knowledge/problems/things/ judgements" was lowest in the last year, the percentage of the students who constructed theorem with "axiom/hypothesis" which already have truth was highest in the same year. The expressions of the students coded $12 / 20,09 / 80$ and 13/71, in this group, are given below.

$12 / 20$. They are the propositions whose truth can be proven.

09/80. They are the hypotheses whose truth has been proven.

13/71. The axioms whose truth can be proven are called theorems.

More than half of the students $(61.29 \%)$ who constructed theorem with "proving-accepting truth or falsity" did this by associating it with "proposition" and the others $(39.71 \%)$ with "statements/judgements/axioms/hypotheses. The expressions of the students in this group coded 11/23 and 13/94 are as follows.

$11 / 23$. They are the mathematical expressions whose truth or falsity can be proven.

$13 / 94$. They are the axioms whose truth or falsity can be proven. 
Table 5. Sub-categories of Each of the Categories of the Answers Given by Students to the Question on Theorem and Their Distribution by Years

\begin{tabular}{|c|c|c|c|c|c|c|c|c|c|c|c|c|}
\hline \multirow[b]{2}{*}{ Sub-categories } & \multicolumn{2}{|c|}{$2009-2010$} & \multicolumn{2}{|c|}{$2010-2011$} & \multicolumn{2}{|c|}{ 2011-2012 } & \multicolumn{2}{|c|}{$2012-2013$} & \multicolumn{2}{|c|}{$2013-2014$} & \multicolumn{2}{|c|}{5 years } \\
\hline & $\mathrm{n}$ & $\%$ & $\mathrm{n}$ & $\%$ & $\mathrm{n}$ & $\%$ & $\mathrm{n}$ & $\%$ & $\mathrm{n}$ & $\%$ & $\mathrm{n}$ & $\%$ \\
\hline Constructions with "Proof" & & & & & & & & & & & & \\
\hline $\begin{array}{l}\text { Propositions which are accepted as } \\
\text { they have been proven- as they can } \\
\text { be proven- without proof }\end{array}$ & 6 & 33.33 & 1 & 50 & 1 & 50 & 2 & 28.57 & 14 & 42.43 & 24 & 38.71 \\
\hline $\begin{array}{l}\text { Statements/Knowledge/Problems/Th } \\
\text { ings which are accepted as they } \\
\text { have been proven- as they can be } \\
\text { proven- without proof }\end{array}$ & 8 & 44.44 & - & - & 1 & 50 & 5 & 71.43 & 7 & 21.21 & 21 & 33.87 \\
\hline $\begin{array}{l}\text { Axioms/hypotheses which are } \\
\text { accepted as they have been proven- } \\
\text { as they can be proven- without } \\
\text { proof }\end{array}$ & 3 & 16,67 & 1 & 50 & - & - & - & - & 12 & 36.36 & 16 & 25.81 \\
\hline Other & 1 & 5,56 & - & - & - & - & - & - & - & - & 1 & 1.61 \\
\hline Total & 18 & 100 & 2 & 100 & 2 & 100 & 7 & 100 & 33 & 100 & 62 & 100 \\
\hline
\end{tabular}

Constructions by "Proving-Accepting Truth"

Propositions whose truth is accepted as it has been proven- as it can be proven- without proof $\begin{array}{llllllllllll}23 & 56.10 & 20 & 64.52 & 25 & 73.53 & 18 & 60 & 13 & 52.00 & 99 & 61.49\end{array}$

Statements/Knowledge/Problems/Th ings/Judgements whose truth is accepted as it has been proven- as it $\begin{array}{llllllllllll}13 & 31.71 & 11 & 35.48 & 8 & 23.53 & 11 & 36.67 & 5 & 20.00 & 48 & 29.81\end{array}$ can be proven- without proof Axioms/hypotheses whose truth is $\begin{array}{llllllllllllll}\text { accepted as it has been proven- as it } & 5 & 12.19 & - & - & 1 & 2.94 & 1 & 3.33 & 7 & 28.00 & 14 & 8.70\end{array}$ can be proven- without proof

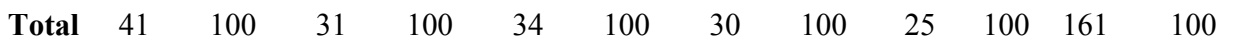

Constructions by "Proving-Accepting Truth or Falsity"

Propositions whose truth or falsity can be proven-questioned-known-which is not certain

Statements/judgements/axioms/hypo theses whose truth or falsity can be proven-questioned-which is $\begin{array}{llllllllllll}1 & 16.67 & 2 & 66.67 & 2 & 50 & 1 & 25.00 & 6 & 42.86 & 12 & 39.71\end{array}$ known-not certain-not known

$\begin{array}{lllllllllllll}\text { Total } & 6 & 100 & 3 & 100 & 4 & 100 & 4 & 100 & 14 & 100 & 31 & 100\end{array}$

\subsubsection{Proof}

Sub-categories of each category of the student answers to the question "Define proof" and their distribution by years are shown in Table 6. 
Table 6. Sub-categories of Each Category of the Student Answers to the Question on Proof and Their Distribution by Years

\begin{tabular}{|c|c|c|c|c|c|c|c|c|c|c|c|c|}
\hline \multirow{2}{*}{ Sub-categories } & \multicolumn{2}{|c|}{$2009-2010$} & \multicolumn{2}{|c|}{$2010-2011$} & \multicolumn{2}{|c|}{ 2011-2012 } & \multicolumn{2}{|c|}{$2012-2013$} & \multicolumn{2}{|c|}{ 2013-2014 } & \multicolumn{2}{|c|}{5 years } \\
\hline & $\mathrm{N}$ & $\%$ & $\mathrm{n}$ & $\%$ & $\mathrm{n}$ & $\%$ & $\mathrm{n}$ & $\%$ & $\mathrm{~N}$ & $\%$ & $\mathrm{n}$ & $\%$ \\
\hline \multicolumn{13}{|l|}{ Constructing with theorem } \\
\hline $\begin{array}{l}\text { Ways/methods/operations of showing } \\
\text { the truth of a theorem }\end{array}$ & 19 & 46.34 & 10 & 41.67 & 6 & 30 & 6 & 31.58 & 11 & 26.19 & 52 & 35.62 \\
\hline $\begin{array}{l}\text { Ways/methods/operations of showing } \\
\text { the truth or falsity of a theorem }\end{array}$ & 10 & 19.50 & 6 & 16.67 & 2 & 10 & 1 & 5.26 & 6 & 14.29 & 25 & 17.12 \\
\hline Proving the truth of theorems & 3 & 7.32 & 3 & 12.50 & 4 & 20 & 4 & 21.05 & 11 & 26.19 & 25 & 17.12 \\
\hline Proving the truth or falsity of theorems & 2 & 4.88 & 2 & 8.33 & 1 & 5 & 2 & 10.53 & 7 & 16.67 & 14 & 9.59 \\
\hline Proving a theorem & 6 & 7.32 & 2 & 8,33 & 2 & 10 & 4 & 21.06 & 4 & 9.52 & 18 & 12.33 \\
\hline Methods of finding theorems and others & 1 & 2.44 & 1 & 4.17 & 5 & 25 & 2 & 10.52 & 3 & 7.14 & 12 & 8.22 \\
\hline Total & 41 & 100 & 24 & 100 & 20 & 100 & 19 & 100 & 42 & 100 & 146 & 100 \\
\hline \multicolumn{13}{|l|}{ Constructing with proposition } \\
\hline $\begin{array}{l}\text { Ways/methods/operations of } \\
\text { finding-showing the truth of a } \\
\text { proposition }\end{array}$ & 5 & 45.45 & 3 & 50 & 3 & 27.27 & 1 & 25 & 2 & 28.57 & 14 & 35.90 \\
\hline $\begin{array}{l}\text { Ways/methods/operations of } \\
\text { finding-showing the truth or falsity of a } \\
\text { proposition }\end{array}$ & 4 & 36.37 & 3 & 50 & 7 & 63.63 & 2 & 50 & 3 & 42.86 & 19 & 48.72 \\
\hline Proving the truth of a proposition & 2 & 18.18 & - & - & 1 & 9.10 & 1 & 25 & 2 & 28.57 & 6 & 15.38 \\
\hline Total & 11 & 100 & 6 & 100 & 11 & 100 & 4 & 100 & 7 & 100 & 39 & 100 \\
\hline \multicolumn{13}{|l|}{ Constructing with axiom } \\
\hline $\begin{array}{l}\text { Ways/methods/operations of } \\
\text { proving-showing the truth of an axiom }\end{array}$ & 1 & 100 & - & - & - & - & - & - & 1 & 100 & 2 & 40 \\
\hline $\begin{array}{l}\text { Ways/methods/operations of showing } \\
\text { the truth or falsity of an axiom }\end{array}$ & - & - & - & - & 1 & 100 & 2 & 100 & - & - & 3 & 60 \\
\hline $\begin{array}{rr}\text { Total } \\
\end{array}$ & 1 & 100 & - & - & 1 & 100 & 2 & 100 & 1 & 100 & 5 & 100 \\
\hline \multicolumn{13}{|l|}{ Constructing with hypothesis } \\
\hline $\begin{array}{l}\text { Ways/methods/operations of showing } \\
\text { the truth of a hypothesis }\end{array}$ & 1 & 100 & 2 & 100 & 3 & 75 & - & - & 2 & 66.7 & 8 & 80 \\
\hline $\begin{array}{l}\text { Ways/methods/operations of showing } \\
\text { the truth or falsity of a hypothesis }\end{array}$ & - & - & - & - & 1 & 25 & - & - & 1 & 33.3 & 2 & 20 \\
\hline Total & 1 & 100 & 2 & 100 & 4 & 100 & - & - & 3 & 100 & 10 & 100 \\
\hline \multicolumn{13}{|c|}{ Constructing with Formulae, Expressions, Operations, Problems, Questions, and Equalities } \\
\hline $\begin{array}{l}\text { Ways/methods/operations of showing } \\
\text { the truth of an expression, operation, } \\
\text { problem, formula, equality, rule, } \\
\text { judgement, knowledge whose truth has } \\
\text { not been proven, and a mathematical } \\
\text { expression }\end{array}$ & 3 & 30 & 3 & 50 & 4 & 66.67 & 2 & 22,22 & 4 & 26.67 & 16 & 34.78 \\
\hline $\begin{array}{l}\text { Ways/methods/operations of showing } \\
\text { the truth or falsity of an expression, } \\
\text { operation, problem, formula, equality, } \\
\text { rule, judgement, knowledge whose } \\
\text { truth has not been proven, and a } \\
\text { mathematical expression }\end{array}$ & 3 & 30 & 2 & 33.33 & - & - & 6 & 66.67 & 6 & 40.00 & 17 & 36.96 \\
\hline Other & 4 & 40 & 1 & 16.67 & 2 & 33.33 & 1 & 33.33 & 5 & 33.33 & 13 & 28.26 \\
\hline Total & 10 & 100 & 6 & 100 & 6 & 100 & 9 & 100 & 15 & 100 & 46 & 100 \\
\hline
\end{tabular}


As it is seen in Table 6, the students who constructed "proof" with "theorem" did this most (35.62\%) by associating it with "showing the truth of theorems" and least (\%8.22) with "Methods of finding theorems and others". While the percentage of associating with "showing the truth of theorems" was $46.34 \%$ in the first year, it became $26.19 \%$ in the last year with a significant decline. Although the overall percentages of associating with "showing the truth or falsity of theorems" and "proving the rightness of theorems" are equal (\%17.12) and the percentage of the former decreased in the first four years and increased in the last, the percentage of the latter constantly increased over years. In addition, while the percentage of associating with "proving the truth or falsity of theorems" was $4.88 \%$ in the first year, with a great increase, it became $16.67 \%$ in the last year. Whereas the percentage of associating with "proving theorems" constantly increased in the first four years, in the last year, it declined to the mean of the first three years. The expressions of the students coded 09/81, 10/41,11/32, 12/19 and 13/101 are introduced below.

$09 / 81$. It is proving the truth or falsity of a theorem.

10/41. The combination of all the processes-operations used to show the truth or falsity of theorems is called proof.

11/32. It is a method used to find the truth of a theorem.

$12 / 19$. It is a way followed to prove a theorem.

13/101. It is a method used to prove the truth of a theorem.

The students who constructed proof with "proposition" did this by associating it most (48.72\%) with "showing the truth or falsity of proposition" and least with (15.38\%) "proving the truth of proposition". Also, more than one out of three of the students in this group (35.90\%) made their associations with "finding-showing the truth of proposition". Of these students, the expressions of those coded 09/67, 11/38 and 13/54 are exemplified below.

09/67. It is proving the truth of a proposition.

$11 / 38$. It is finding the precise truth or falsity of a proposition.

$13 / 54$. Showing the truth or falsity of a given proposition is called proof.

The students who constructed proof with "axiom" and "hypothesis" did this by associating it with either "proving-finding-showing its truth" or "proving-finding-showing its truth or falsity". The expressions of the students, in this group, coded $11 / 11$ and $13 / 12$ are as follows.

11/11. It is a process of proving done to find out whether an axiom is true or false.

13/12. It is finding or proving that an axiom is true.

The students who constructed proof with "formula, expression, operation, problem, question, and equation" did this by associating it with, with a percentage of $34.78 \%$, "proving-finding-showing its truth" and, with a percentage of $36.9 \%$, with "proving-finding-showing its truth or falsity". No common mathematical content was found in the expressions of the other (28.26\%) students. The expressions of the students in this group coded 10/4 and 13/17 are introduced below.

10/4. The activities done in order to show whether a sentence or rule is true or false is called proof.

13/57. It is an explanation made for indicating that an equation or statement is true.

\section{Conclusion, Discussion and Suggestions}

In this section, the findings presented in findings section were discussed under the titles of "proposition", "theorem" and "proof" and some suggestions on how to teach these concepts were given.

\subsection{Proposition}

According to the means of five years, most of the students' constructions of the concept of proposition and content construction of it match each other. This rate is higher than the one reported in Dane's study (2008) "Slightly more than one out of three (34\%) of the students defined the concept of proposition right" and reveals a more positive result in terms of students' learning the concept of proposition. Emphasis of high school mathematics teaching programs on conceptual learning can be shown as the reason of this change. This finding may also be attributed to reflections of the studies started with these researchers in teacher education. While the percentages of constructions of proposition consistent with the content construction of the concept increased in the first three years, they decreased in the last two years and, in the last year, became even lower than the percentage of the first year. Similarly, although the percentages of those who could not construct the concept of proposition in line with the 
content construction are close to each other in the first and last year, they were highest in the second and lowest in the fourth year. The cause underlying this case may be the possibility of the existence of high schools which do not put enough emphasis on conceptual learning due to some reasons such as university entrance examinations. This point is suggested to be researched.

According to the mean of five years, the proposition constructions of more than one out of three of the students do not match the content construction of the same concept. Some of these students used the conditions that could not make a sentence a proposition as the mathematical content in their constructions. This finding is in parallel with Dane's (2008) finding that "Students have alternative concepts related to proposition and, accordingly, so many misconceptions". The reason for this may be not emphasizing that sentences should necessarily have an either true or false judgement while giving the students samples of propositions. In addition, some of the students who could not construct proposition in line with the content construction of it, as understood from their expressions, perceived it as an argument that should necessarily be proven. While this perception may be attributed to external factors such as introduction of a proposition and an immediate provision of a proof for it in mathematics textbooks or mathematics teaching process, it may also be attributed to that students may mistake (as in a student's expression, "I do not think proposition is much different from theorem because, in some textbooks, proposition is used for theorem" in Dane's study (2008)) the concepts of open proposition (proposition-like form) and proposition for each other. This is also an important point suggested to study on.

The results of the study in the 2011-2012 and 2012-2013 academic years are far better than the results of other years in terms of right and false answer percentages. The reason for this can be students' level depending on the placement scores in entering university. This is also among the points which are suggested to be studied on.

The increase in the number of the students who gave no answer in the last year is a finding which should be seriously dealt with.

\subsection{Theorem}

Nearly half (48.94\%) of the students used the mathematical expression "proving-accepting truth" in their constructions of theorem. The reason for this may be that the definitions given in the introductory part may have caused them to focus proving "truth". Thus, some students may have developed a tendency to prove the truth of "axioms-hypotheses-equation-formula-knowledge-problem-judgement" and perceived them as theorems. This supports Dane's (2008) finding "Students have alternative concepts of theorem and, therefore, have many misconceptions". This finding supports also Ersoy and Erbaş's (2005) result that "there are some misconceptions about the concepts of equation and variable". Although, in the abstract mathematics course at the tertiary level, whenever a "theorem" is given and a "proof" is provided, a special emphasis was put on "hypothesis and judgement" and this is highlighted in both written and oral means in students' practices, the percentage of their use of the mathematical content "hypothesis and judgement" in their construction of theorem over five years was very low (6.08\%). This result reveals the importance (retention) of previous constructions again. When the previous constructions which are not consistent with content structure are recognized as true in examinations and reinforced with marks, retention turns into knowledge conservatism which becomes too difficult to change. For this reason, high school mathematics teachers and university lecturers who teach such core courses should follow the content structure while constructing theorems.

\subsection{Proof}

In constructing the concept of proof, students used the mathematical content theorem most(44.38\%).The reason for this may be the emphasis put on "proof" in some theorem definitions. In this case, Nasibov and Kaçar's suggestion (2005) "It is very important to show that each of the conditions in theorems are used in proofs and how it is done" should be taken into consideration. Some students used the mathematical contents "Formula, Expression, Operation, Problem, Question, Judgement, and Equation". Its reason may be teachers' not using the mathematical language including the expressions such as "prove the equation" in an appropriate way. This result is in parallel with the finding of Güler and Dikici (2012) that "For most of the teachers, the purpose of mathematical proof is the affirmation of mathematical expressions". Also, what the students understand from formula, expression, operation, problem, question, judgement, and equation is suggested to be searched. Some students, on the other hand, used the mathematical content proposition in their constructions of proof. This may be associated with the introduction of proposition and then immediately its proof in some mathematics reference books and course-books. These results support Weber's (2001) result that "Most of university students have the knowledge which they need to prove a statement but have difficulties with doing this". 
Here it is understood that the definition "the propositions which are proven to be true are theorems" is not clear enough. This result is in line with the results of Rasmussen (1998) "the confusion stemming from non-standard and intuitive concepts", Tatar and Dikici (2008) "Learning difficulties stemming from the gaps in mathematics teaching practices", Güler and Dikici (2012) "there is a relationship between the differences between the proves the students were successful or failed in and how well they had learned the concepts related to proof". The point that the proposition given and supposed to be proven in this definition is the proposition "as long as the hypothesis is true the judgement is true"is missed. It should be clarified that this proposition, with this form, is an open proposition and, in this open proposition, if "a true proposition or an axiom or a proposition whose truth will be shown and is called Lemma instead of hypothesis, and instead of "consequent" "a proposition" are written, it will be called theorem.

It seems impossible to construct the concepts of theorem and proof before the construction of the concept of proposition in consistency with its content structure. Also, the difference and relationship between an open proposition and a proposition should be taught well first and then the difference and relationship between a conditional proposition and the preposition " $\Rightarrow$ " and finally requirement of one proposition of another and "necessary and sufficient condition". Later, the terms hypothesis and result included in the definition of theorem should be explained and what can be written as hypotheses and what as consequents should be clarified and some practice should be done. For this purpose, first the theorems available should be used and then students should be given the opportunity to produce their own theorems. In addition, it can make the task easier to give examples from daily life suitable to this cycle. After these processes it should be stated that proof refers to that when the proof is true, the consequent is true as well and each of the methods for doing this should be given with ample exemplification. Students should be asked to prove the theorems they write and practices or experiences related to the methods they want to use should be provided.

\section{References}

Akkaş, S., Hacısalihoğlu, H., Özel, Z., \& Sabuncuoğlu, A. (1998). Soyut matematik [Abstract mathematics](3rd Ed.). Ankara: Gazi University Press.

Almeida, D. (2000). A survey of mathematics undergraduates interaction with proof: Some implications for mathematics education. International Journal of Mathematical Education in Science and Technology, 31(6), 869-890. http://dx.doi.org/10.1080/00207390050203360

Almeida, D. (2003). Engendering proof attitudes: Can the genesis of mathematical knowledge teach us anything? International Journal of Mathematical Education in Science and Technology, 34(4), 479-488. http://dx.doi.org/10.1080/0020739031000108574

Arslan, Ç. (2007). Illköğretim öğrencilerinde muhakeme etme ve ispatlama düşüncesinin gelişimi. Unpublished doctoral dissertation, Uludağ University, Bursa, Turkey.

Arslan, S., \& Y1ldiz, C. (2010). Reflections from the Experiences of $11^{\text {th }}$ Grades during Stages of Matematical Thinking. Education and Science, 35(156), 17-31.

Aydoğdu, T., Olkun, S., \& Toluk, Z. (2003). İlköğretim öğrencilerinin çözdükleri matematik problemlerini kanıtlama süreçleri. Eğitim Araştırmaları, 4(12), 64-74.

Bahtiyari, Ö., A. (2010). Sekizinci sinlf matematik ögretiminde ispat ve muhakeme kavramlarının ve önemlerinin farkındalığ. Unpublished master's thesis. Atatürk University, Erzurum, Turkey.

Ball, D. L. (1991). Research on teaching mathematics: Making Subject-matter knowledge part of the equation. In J. Brophy (Ed.), Advances in research on teaching (pp. 1-48). Greenwich: JAI Press.

Bayazıt, İ., \& Aksoy, Y. (2010). Öğretmenlerin fonksiyon kavramı ve öğretimine ilişkin pedagojik görüşleri. University of Gaziantep Journal of Social Sciences, 9(3), 697-723.

Bravo, H. (2010). Locke'un soyut genel ide anlayışı. FLSF (Felsefeve Sosyal Bilimler Dergisi), 10, 95-115.

Çelebi, O., \& Çakar, Ö. (1993). Soyut matematik [Abstract mathematics]. Ankara: Ankara Üniversitesi Döner Sermaye Yayınları.

Coe, R., \& Ruthven, K. (1994). Proof practices and constructs of advanced mathematics students. British Educational Research Journal, 20(1), 41-54.

Coşkun, F. (2009). Ortaöğretim öğrencilerinin Van Hiele geometri anlamaseviyeleri ile ispat yazma becerilerinin ilişkisi. Unpublished master's thesis. Karadeniz Teknik University, Trabzon, Turkey. 
Dane, A. (2008). İlköğretim matematik 3. Sınıf öğrencilerinin tanım, aksiyom ve teorem kavramlarını anlama düzeyleri. Kastamonu Ë̆itim Dergisi, 16(2), 495-506.

Dickersen, D. (2006). Aspects of preservice teachers' understandings of the purpose of mathematical proof. USA: Psychology of Mathematics and Education of North America, 2006 Annual Meeting.

Dönmez, A. (1987). Kümeler kuramı ve soyut matematik [Sets theory and abstract mathematics]. Erzurum: Atatürk Üniversitesi Basımevi.

Dreyfus, T. (1999). Why Johnny can't prove. Educational Studies in Mathematics, 38(1), 85-109. http://dx.doi.org/10.1023/A:1003660018579

Ersoy, Y., \& Erbaş, A.K. (2005). Kassel projesi cebir testinde bir grup Türk öğrencinin genel başarısı ve öğrenme güçlükleri. Illköğretim-Online, 4(1), 18-39. Retrieved August 5, 2014 from http://www.ilkogretim-online.org.tr

Escudero, I., \& Sanchez, V. (2002). Integration of domains of knowledge in mathematics teachers' practice. In Cockburn \& Nardi (Eds.), Proceedings of the 26 Conference of international group of PME (Vol. 2, pp. 177-184).

Güler, G., \& Dikici, R. (2012). Ortaöğretim matematik öğretmeni adaylarının matematiksel ispat hakkındaki görüşleri. Kastamonu Eğitim Dergisi, 20(2), 571-590.

Güven, B., Çelik, D., \& Karataş, İ. (2005). Ortaöğretimdeki çocukların matematiksel ispat yapabilme durumlarının incelenmesi. Çăgdaş Ĕ̈itim Dergisi, 30, 319.

Hanna, G. (2000). Proof, explanation and exploration: An overview. Educational Studies in Mathematics, 44, 5-23. http://dx.doi.org/10.1023/A:1012737223465

Harel, G. (2008). DNR perspective on mathematics curriculum and instruction, Part I: focus on proving. ZDM Mathematics Education, 40, 487-500. http://dx.doi.org/10.1007/s11858-008-0104-1

Harel, G., \& Sowder, L. (1998). Students' proof schemes: Results from exploratory studies. In A. Schoenfeld, J. Kaput and E. Dubinsky (Eds.), Research in collegiate Mathematics Education III (pp. 234-283). Providence, RI: American Mathematical Society.

Harel, G., \& Sowder, L. (2007). Toward a comprehensive perspective of proof. In F. Lester (Ed.), Handbook of research on teaching and learning mathematics (Vol. 2), NCTM.

Heinze, A., \& Reiss, K. (2003). Reasoning and proof: Methodological knowledge as a component of proof competence. In M.A. Mariotti (Ed.), Proceedings of the third conference of the European society for research in Mathematics education. Bellaria, Italy.

Hirst, H. P., \& Hirst, J. L. (2004). A primer for logic and proof. Retrieved August, 6, 2014 from http://nozdr.ru/data/media/biblioteka/kolxo3/M_Mathematics/MA_Algebra/MAml_Mathematical\%20logic/Hirs t\%20H.P.,\%20Hirst\%20J.L.\%20A\%20primer\%20for\%20logic\%20and\%20proof\%20(web\%20draft,\%202004)( 98s)_MAml_.pdf

İmamoğlu, Y. (2010). Birinci ve son sinıf matematik ve matematik ögretmenliği öğrencilerinin ispatla ilgili kavramsallaştırma ve becerilerinin incelenmesi. Unpublished doctoral dissertation.Boğaziçi University, İstanbul, Turkey.

Irmak, H. (2008). Soyut matematik [Abstract mathematics]. Ankara: PegemAkademi.

İskenderoğlu, T. A., Baki, A., \& Palanci, M. (2011). Matematiksel kanıt yapmaya yönelik görüş ölçeği: Geçerlik ve güvenirlik çalışması. Necatibey Faculty of Education Electronic Journal of Science \& Mathematics Education, 5(1), 181-203.

Jones, K. (1997). Student teachers' conceptions of mathematical proof. Mathematics Education Review, 9, 21-32.

Jones, K. (2000). The student experience of mathematical proof at university level. International Journal of Mathematical Education in Science and Technology, 31(1), 53-60. http://dx.doi.org/10.1080/002073900287381

Karasar, N. (2008). Bilimsel araştırma yöntemleri [Scientific research methods]. Ankara: Nobel Yayın Dağııım.

Knuth, E. J. (2002). Teachers' conceptions of proof in the context of secondary school mathematics. Journal of Mathematics Teacher Education, 5, 61-88. http://dx.doi.org/10.1023/A:1013838713648

Martin, G., \& Harel, G. (1989). Proof frames of pre-service elementary teachers. Journal for Research in Mathematics Education, 20(1), 41-51. http://dx.doi.org/10.2307/749097 
Milli Eğitim Bakanlığı [National Ministry of Education] (2011). Ortaögrretim matematik 9. sinıf ders kitabı (Devlet Kitapları Birinci Baskı). İstanbul: İhlasGazetecilik A.Ş.

Moore, R. C. (1990). College students' difficulties in learning to do mathematical proofs. Unpublished doctoral dissertation, University of Georgia, Georgia.

Moore, R. C. (1994). Making the transition to formal proof. Educational Studies in Mathematics, 27, 249-266. http://dx.doi.org/10.1007/BF01273731

Moralı, S., Köroğlu, H., \& Çelik, A. (2004). Buca Eğitim Fakültesi matematik öğretmenadaylarının soyut matematik dersine yönelik tutumları ve rastlanan kavram yanılgıları. Gazi Üniversitesi, Gazi Eğitim Fakültesi Dergisi, 24(1), 161-175.

Moralı, S., Uğurel, I., Türnüklü, E., \& Yeşildere, S. (2006). Matematik öğretmen adaylarının ispat yapmaya yönelik görüşleri. Kastamonu Eğitim Dergisi, 14(1), 147-160.

Nasibov, F. H., \& Yetim, S. (2008). Elemanter matematik ve yüksek matematik kavramları hakkında. FiratÜniv. Fen veMüh.Bil.Dergisi, 20(3), 423-431.

Nasibov, F., \& Kaçar, A. (2005) Matematik ve matematik eğitimi hakkında. Kastamonu Eğitim Dergisi, 13(2), 339-346.

NCTM (2000). Principles and standards for school mathematics. Reston, Virginia: NCTM.

Özer, Ö., \& Arıkan, A. (2002). Lise matematik derslerinde öğrencilerin kanıt yapabilme düzeyleri. In the proceedings books of $V$. Fen Bilimleri ve Matematik Eğitimi Kongresi, 16-18 September, Vol. II (pp. 1083-1089), Ankara.

Özer, O., Çoker, D., \& Taş, K. (1999). Soyut matematik [Abstract mathematics]. Bilim Yayınları.

Özmantar. M. F., \& Bingölbali, E. (2010). Sınıföğretmenlerivematematikselzorlukları. Gaziantep Üniversitesi Sosyal Bilimler Dergisi, 8(2), 401-427.

Raman, M. J. (2002). Proof and justification in collegiate calculus. Unpublished doctoral dissertation. University of California, Berkeley.

Raman, M. J. (2003). Key ideas: What are they and how can they help us understand how people view proof? Educational Studies in Mathematics, 52(3), 319-325. http://dx.doi.org/10.1023/A:1024360204239

Rasmussen, C. L. (1998). Reform in differential equations: A case study of students' understandings and difficulties. The Annual Meeting of American Educational Research Association, San Diego, CA. Retrieved August, 12, 2014 from http://files.eric.ed.gov/fulltext/ED420508.pdf

Recio, A. M., \& Godino, J. D. (2001). Institutional and personal meanings of mathematical proof. Educational Studies in Mathematics, 48(1), 83-89. http://dx.doi.org/10.1023/A:1015553100103

Sarı, M., Altun, A., \& Aşkar, P. (2007). Üniversite öğrencilerinin analiz dersi kapsamında matematiksel kanıtlama süreçleri: Örnek olay çalı̧̧ması. Ankara Üniversitesi EğitimBilimleri Fakültesi Dergisi, 40(2), 295-319.

Schoenfeld, A. H. (1994). Reflections on doing and teaching mathematics. Mathematical Thinking and Problem Solving, 53-69.

Selden, A., \& Selden, J. (2003). Validations of proofs considered as texts: Can undergraduates tell whether an argument proves a theorem? Journal for Research in Mathematics Education, 34(1), 4-36. http://dx.doi.org/10.2307/30034698

Shipley, A. J. (1999). An investigation of collage students' understanding of proof construction when doing mathematical analysis proofs. Unpublished doctoral dissertation, University of American, Washington.

Shulman, L. (1986). Those who understand: Knowledge growth in teaching. Educational Researcher, 15, 4-14. http://dx.doi.org/10.3102/0013189X015002004

Solomon, Y. (2006). Deficit or difference? The role of students' epistemologies of mathematics in their interactions with proof. Educational Studies in Mathematics, 61(3), 373-393. http://dx.doi.org/10.1007/s10649-006-6927-1

Stylianides, G. J., Stylianides, A. J., \& Philippou, G.N. (2007). Pre-service teachers' knowledge of proof by mathematical induction. Journal of Mathematics Teacher Education, 10, 145-166. http://dx.doi.org/10.1007/s10857-007-9034-z

Tall, D., \& Mejia-Ramos, J. P. (2006). The long-term cognitive development of different types of reasoning and 
proof. Paper presented in Conference on Explanation and Proof in Mathematics: Philosophical and Educational Perspectives, Universitat Duisburg-Essen, November 1-4, 2006.

Tatar, E., \& Dikici, R. (2008). Matematik eğitiminde öğrenme güçlükleri. Mustafa Kemal Üniversitesi Sosyal Bilimler Enstitüsü Dergisi, 5(9), 183-193.

Tirosh, D., Even, R., \& Robinson, N. (1998). Simplifying algebraic expressions: Teacher awareness and teaching approaches. Educational Studies in Mathematics, 35, 51-64. http://dx.doi.org/10.1023/A:1003011913153

VanSpronsen, H. D. (2008). Proof processes of novice mathematics proof writers. Unpublished doctoral dissertation, University of Montana.

Weber, K. (2001). Student difficulty in constructing proof: The need for strategic knowledge. Educational Studies in Mathematics, 48(1), 101-119. http://dx.doi.org/10.1023/A:1015535614355

Weber, K. (2005). Problem solving, proving and learning: The relationship between problem solving processes and learning opportunities in the activity of proof construction. Journal of Mathematical Behaviour, 24, 351-360. http://dx.doi.org/10.1016/j.jmathb.2005.09.005

Yeşildere, S., \& Akkoç, H. (2010). Matematik öğretmen adaylarının sayı örüntülerine ilişkin pedagojik alan bilgilerinin konuya özel stratejiler bağlamında incelenmesi. Ondokuz Mayıs̈̈niversitesi Eğitim Fakültesi Dergisi, 29(1), 125-149.

Yıldırım, A., \& Şimşek, H. (2005). Sosyal bilimlerde nitel araştırma yöntemleri[Qualitative research methods in social sciences]. Ankara: SeçkinYayınları. 